\title{
ROLE OF SOCIAL DIALOGUE WITHIN PARTNERSHIP APPROACH TO EUROPEAN COHESION POLICY AND CROATIA EXPERIENCES
}

\author{
Berislav Andrlić, Marko Šostar, \& Antun Marinac \\ Polytechnic of Požega (Republic of Croatia)
}

\begin{abstract}
The aim of the research is to analyse the role of social dialogue within the partnership approach in European cohesion policy. Since the Republic of Croatia has become a member of the European Union in 2013, the objective is also to analyse the Croatian experience in this area. The fundamental objective of the European cohesion policy is to equalize regional inequalities across the entire territory of the European Union. In order to achieve this goal, among other things, it was necessary to establish a partnership, and social dialogue has a significant role within this partnership. There is a close link between partnership and multi-level governance (European, national, regional and local). These are the key principles underpinning the European Cohesion Policy. Partnership and social dialogue are particularly pronounced when concluding a partnership agreement, which is a novelty in the programming period of cohesion policy from 2014 to 2020. In doing so, each Member State, in accordance with its institutional and legal framework, has the obligation to organize a partnership with the competent regional and local authorities. Each EU Member State is required to prepare Partnership Agreements (Vertical Partnerships) in cooperation with partners as defined in the legally binding EU Regulation (EU) No. 1303/2013 and in dialogue with the European Commission. The Partnership Agreement establishes the mechanisms of a Member State for the effective and efficient use of the European Structural and Investment Funds. Partnership, in particular, includes social partners who, through negotiations and consultations in shaping the European Cohesion Policy, define social dialogue. The said Regulation stipulates that the partnership agreement must be in accordance with the principles of subsidiarity and proportionality, thus favouring the involvement of social partners at local level.

Given the fact that the Agreement on Partnership between the Republic of Croatia and the European Commission on the use of EU Structural and Investment Funds for Growth and Jobs in the period 2014-2020 has been adopted at the EU level, Croatia's experience in these activities is also analysed.
\end{abstract}

Keywords: Member States, European Union, Cohesion Policy, social dialogue, multilevel management.

\section{Introduction}

There is a growing need for involvement of various partners, especially social partners, through social dialogue in the implementation of public policies. Among these policies, the European Cohesion Policy, which is also called regional i.e. solidarity policies, has a significant role. In the EU legal system, it appears under the term "Economic, Social and Territorial Cohesion". From the term itself, it is possible to see that this policy, along with economic and territorial, also includes the social component.

Reducing regional inequality represents the main objective of cohesion policy, primarily through European Structural and Investment Funds (ESI Funds). Even in the 1958 Treaty establishing the European Economic Community (EEC), Rome, 25 March 1957, entry into force on 1 January 1958, the founders of the European Community expressed "the desire to reduce the differences that exist between individual regions" and to reduce the backwardness of the regions in disadvantaged position. By this act and establishing two Structural Funds (European Social Fund and European Agricultural Guidance and Guarantee Fund), the foundations of cohesion policy have been established. It later developed into one of the most prominent European financial policies in the financial sense, which in this period (2014-2020) has funds amounting to $1 / 3$ of the European budget.

The existence of regional inequalities came to the fore after the accession of the poorer countries to the EU and that has resulted in consequences that were of social nature. Their underdeveloped regions exhibit poverty; social exclusion, high unemployment rate, as well as population leaving the underdeveloped areas. These consequences are also felt in the territory of the Republic of Croatia. Therefore, the application of social dialogue through a partnership approach in the European cohesion policy is logical. 


\section{Social dialogue at the European Level}

At the European level, social dialogue is an integral part of the EU acquis communautaire. This, in the first place, confirms the Treaty on the Functioning of the European Union as the underlying treaty on which the Union is founded. This Treaty stipulates that the Union recognizes and promotes the role of social partners at their level, taking into account the diversity of national systems. In doing so, the Union facilitates dialogue among social partners, respecting their autonomy (Consolidated versions of the Treaty on European Union and the Treaty on the Functioning of the European Union, Official Journal of the European Union, C 202, Volume 59 Information and Notices 7 June 2016, article 152).

Among the more important documents at the European level, the EU Strategy entitled "Europe 2020: A Strategy for Smart, Sustainable and Inclusive Growth" is also mentioned, which in the pursuit of its goals advocates social dialogue through the strengthening of the capacities of social partners. This implies full use of the potential for problem-solving social dialogue at all levels (from the EU, national / regional, sectorial, within enterprises). In this context, the Strategy publishes a strong incentive for a strategic framework for co-operation in education and training involving all stakeholders. This should result in the application of the principle of lifelong learning (in cooperation with Member States, social partners, experts), among other and flexible learning methods between different education sectors and the training sector and their levels. Therefore, the Strategy requires that social partners should be consulted in order to develop their own initiative in this field (Communication from the Commission "Europe 2020: A Strategy for Smart, Sustainable and Inclusive Growth, European Commission, COM (2010) 2020 final, Brussels, 3 March 2010, p.22). This can be achieved, in line with the European Skills, Competences, Qualifications and Occupations Framework (ESCO), through the acquisition of competences throughout the general, vocational, higher education and adult education.

\subsection{Mandatory inclusion of the social partners in the implementation of cohesion policy}

Delegated Regulation of the European Commission (EU) no. 240/2014, under partnership implies a close co-operation between public bodies, economic and social partners and bodies representing civil society at all levels throughout the program cycle of cohesion policy, consisting of preparation, implementation, monitoring and evaluation (Commission Delegated Regulation (EU) No 240/2014 of 7 January 2014 on the European Code of Conduct on Partnership in the framework of the European Structural and Investment Funds, Official Journal of the European Union, 14 March 2014, p.1-7). Social partners imply all participants taking part in social dialogue in various forms of negotiation.

The obligation to include social partners in the implementation of cohesion policy is prescribed by the Regulation (EU) No.1303/2013 (Regulation (EU) No 1303/2013 of the European Parliament and of the Council of 17 December 2013 establishing the European Regional Development Fund, the European Social Fund and the European Agricultural Fund for Rural Development European Maritime and Fisheries Fund and the European Regional Development Fund, the European Social Fund, the Cohesion Fund and the European Maritime and Fisheries Fund and repealing Council Regulation (EC) No 1083/2006, Official Journal of the European Union, L 347/3 320, 20 December 2013). It represents the umbrella policy in the area of cohesion policy and is legally binding for all Member States. The said Regulation lays down the mandatory establishment of multi-level partnerships and management in the area of cohesion policy. According to it, all EU Member States are obliged to conclude a partnership agreement with the European Commission, including programs, and, in accordance with its institutional and legal framework, to organize partnerships with public bodies and other partners as well as social partners.

In Resolution of the European Parliament it is emphasized that in practice uneven progress of Member States occurs in terms of greater mobilization and involvement of social partners in social dialogue on the European structural and investment funds (European Parliament resolution of 13 June 2017 on increasing the engagement of partners and visibility in the Performance of European Structural and Investment Funds (2016/2304 (INI)), Official Journal of the European Union, C 331/2 of 18 September 2018).

\section{Experiences of the Republic of Croatia}

Historically, during the accession negotiations and the accession process of the Republic of Croatia, the role of social partners in the decision-making process has increased.

The Republic of Croatia, as the latest Member State that has joined the EU (since 2013), is obliged to implement European policies, including cohesion policy. Based on that, the Republic of Croatia was required by the European Commission to conclude a partnership agreement, which was accomplished on 30 October 2014 (European Commission adopts 'Partnership Agreement' with Croatia 
on using EU Structural and Investment Funds for growth and jobs in 2014-2020, Brussels, 30 October 2014). Accordingly, the duty of each EU Member State is to submit reports on the progress of the implementation of the EU Partnership Agreement. In the Report by the Republic of Croatia on this issue, Chapter 8 is named "Partner Role in the Implementation of Partnership Agreements". It states that social partners, through social dialogue, are particularly involved in: a) the National Coordination Committee for European Structural and Investment Funds and Instruments of the EU in the Republic of Croatia, b) in the elaboration of the Partnership Agreement of the Republic of Croatia and (operational) programs, Monitoring Committees for each Operational Program and in the work of Evaluation Teams (Progress Report on the Implementation of the Partnership Agreement with the European Union, URL: https://strukturnifondovi.hr/eu-fondovi/esi-fondovi-2014-2020/izvjesca-i-evaluacije/ 01.02.2019).

\subsection{Institutional framework for social partnership and social dialogue}

Social dialogue can be based on direct relationships between social partners themselves ("bipartite") or on relations between government bodies and social partners ("tripartite"). The Labour Act in its Article 285 provides basic assumptions for the establishment of the Economic and Social Council for the purpose of establishing and achieving harmonized activities with a view to the protection and promotion of economic and social rights, i.e. the interests of workers and employers, the pursuit of harmonized economic, social and development policies, the application of collective agreements and their alignment with the measures of economic, social and development policy (Labour Act, Official Journal no. 94/14, 127/17 ). The fundamental task of the Economic and Social Council is to promote the idea of a three-way co-operation between the Government, trade unions and employers' associations on the consideration and resolution of economic and social issues and problems. It is clear from the previous legal provision that an institutional framework for the promotion of social dialogue has been established in Croatia. It consists of the Tripartite Economic and Social Council and its working bodies. Based on this, the partnership is conducted by the Ministry of Labour and Pension System, the Federation of Independent Trade Unions of Croatia and the Croatian Employers' Association. At the same time, this body is an advisory body of the Government. In this way, a tripartite dialogue was established at the national level, and it was further lowered to a lower level, by establishing tripartite bodies in units of local or regional self-government.

Regional Development Act of the Republic of Croatia introduced the principle of partnership, which states that the policy of regional development is based on partnership and cooperation between the public, private and civil sector, which implies cooperation between different partners, including social partners (Regional Development Act of the Republic of Croatia, Official Gazette, no.174/14, Article 5). Pursuant to the aforementioned Act, the Regulation on Founding, Composition, Scope and Modes of the Partnership Councils was adopted (Official Journal, no. 103/15.)

\subsection{Low level of social dialogue}

In general, one can hear the opinion that social dialogue in the Republic of Croatia is still at a low level. The previous statement is also confirmed by the Partnership Agreement between the Republic of Croatia and the EU where it is stated that the cooperation and co-ordination of the public and civilian sector through social dialogue was insufficient for the successful growth, adoption and implementation of integrated local development plans and policies. The inadequate maturity of the local development initiative did not allow local stakeholders sufficient exploitation of local development potential and participation in developing the development paths for their areas. This results in poor involvement of social partners in the development and implementation of both national and European public policies on the Croatian territory (the European Commission adopts 'Partnership Agreement' with the EU's Structural and Investment Funds for growth and jobs in 2014-2020, Brussels, 30 October 2014).

In the context of the implementation of cohesion policy, there are several reasons for a low level of social dialogue. In the Republic of Croatia, the territorial dimension of poverty is particularly pronounced. In this regard, there is evidence that the areas most affected by poverty are areas that were largely affected by war destruction during the Croatian War of Independence and certain border areas and areas of Slavonia. Poverty is particularly high in rural areas, which are faced with huge problems of aging of the population, depopulation, poorer access to services and communal, social and transport infrastructure, making them the most socially vulnerable areas in Croatia (An Analytical Basis for the Progress Report on the Implementation of the Partners hip Agreement between the Republic of Croatia and the European Commission, Institute for Development and International Relations - IRMO, Zagreb, August 2017, p. 65). The fact is that poverty and a high unemployment rate in some regional areas can lead to the weakening of social dialogue and to the dissolution in the opinion of various social partners. Furthermore, there is a lack of capacity at the level of civil society organizations, primarily due to the lack of human and financial resources. In addition, there is insufficient culture of social dialogue in Croatia, as 
well as unsatisfactory level of coordination and partnership among all key stakeholders, resulting in insufficiently developed mobilization potential for citizens and volunteers in the policy development process.

The Partnership Agreement between the Republic of Croatia and the EU offers a solution to strengthen social dialogue and policy formulation and implementation. In this regard, the Agreement states that it is necessary to improve the capacities of civil society organizations and to help them actively engage in policy-making processes and their implementation at all levels of government (local, regional and national). Involvement of stakeholders in these processes encourages increased transparency and trust in public administration and justice and their inclusion, openness and efficiency. For this reason, further efforts should be made to improve coordination between them. In order to increase the contribution of civil society organizations to the development and implementation of public policies at local, regional and national levels, additional investments are needed to strengthen their capacities and create an environment for more open and efficient management models (European Commission adopts 'Partnership Agreement' with Croatia on using EU Structural and Investment Funds for growth and jobs in 2014-2020, Brussels, 30 October 2014).

Unlike Croatia, international analyses show that countries that have developed a quality social dialogue (for example Germany and Slovenia) are countries that have achieved much greater results in the field of development. Therefore, Croatia, as an EU Member State, must invest efforts to strengthen social dialogue, with further development of civil society through a wide range of co-operation modalities, which will be particularly supported through the European Social Fund. This fund can contribute to improving social dialogue, with the help of which it will be ensured that civil society has the capacity to gain influence to participate in the implementation of European policies, particularly cohesion policy.

\section{Conclusion}

In general, it can be concluded that social dialogue is not only relevant in relationships between employers and employees (at enterprise, institutional and industrial level) but is also an important issue in implementing public policies as well. This applies in particular to cohesion policy based on multilevel governance (at European, national and local level). By including social partners in European cohesion policy, they have been given a wide area to participate in shaping this policy. The process of EU enlargement has also promoted social dialogue as a model for participative decision-making.

For the active involvement of social partners in social dialogue, it is necessary to establish a legislative framework that guarantees them an effective functioning. Social dialogue as an integral part of the EU acquis communautaire has a significant place in the European legal system.

Social dialogue, in the implementation phase of cohesion policy, goes down from European to lower levels, primarily at the level of Member States. Similarly, social dialogue is also included in the Croatian legal system. Significant application of social dialogue is at the local level, since the establishment of permanent social dialogue at this level in shaping cohesion policy converges this policy to the public.

In the area of cohesion policy, social partners, through social dialogue, are particularly involved by the National Coordination Committee for European Structural and Investment Funds and the Development of the Partnership and Operational Program through the Operational Programs Monitoring Committee to the Evaluation Steering Group. Nevertheless, in the Republic of Croatia, social dialogue did not develop to an adequate extent. This is particularly characteristic of new Member States, but also of countries with a more pronounced territorial dimension of poverty. For the purpose of strengthening social dialogue, Croatia needs to improve the capacities of civil society organizations, through cooperation that will be particularly supported by the European Social Fund.

\section{References}

An Analytical Basis for the Progress Report on the Implementation of the Partnership Agreement between the Republic of Croatia and the European Commission, Institute for Development and International Relations - IRMO, Zagreb, August 2017.

Commission Delegated Regulation (EU) No 240/2014 of 7 January 2014 on the European code of conduct on partnership in the framework of the European Structural and Investment Funds, Official Journal of the European Union, 14.3.2014.

Communication from the Commission "Europe 2020: A strategy for smart, sustainable and inclusive growth, European Commission, COM (2010) 2020 final, Brussels, 3.3.2010. 
Consolidated versions of the Treaty on European Union and the Treaty on the Functioning of the European Union, Official Journal of the European Union, C 202, Volume 59 Information and Notices 7 June 2016.

European Commission adopts 'Partnership Agreement' with Croatia on using EU Structural and Investment Funds for growth and jobs in 2014-2020, Brussels, 30 October 2014

European Parliament resolution of 13 June 2017 on increasing engagement of partners and visibility in the performance of European Structural and Investment Funds (2016/2304(INI)), Official Journal of the European Union, C 331/2, 18.9.2018.

Law o work, Official Journal no. 94/14, 127/17

Law on Regional Development of the Republic of Croatia, Official Journal no. 174/14.

Progress Report on the Implementation of the Partnership Agreement with the European Union, URL: https://strukturnifondovi.hr/eu-fondovi/esi-fondovi-2014-2020/izvjesca-i-evaluacije/ (01.02.2019.)

Regulation (EU) No 1303/2013 of the European Parliament and of the Council of 17 December 2013 laying down common provisions on the European Regional Development Fund, the European Social Fund, the Cohesion Fund, the European Agricultural Fund for Rural Development and the European Maritime and Fisheries Fund and laying down general provisions on the European Regional Development Fund, the European Social Fund, the Cohesion Fund and the European Maritime and Fisheries Fund and repealing Council Regulation (EC) No 1083/2006, Official Journal of the European Union, L 347/ 320, 20.12.2013.

Regulation on Founding, Composition, Scope and Modes of the Partnership Councils, Official Journal, no. $103 / 15$

Treaty establishing the European Economic Community (EEC), Roma, 25.3.1957, Entry into force 01.01.1958. 